University of Nebraska - Lincoln

DigitalCommons@University of Nebraska - Lincoln

Investigations of the Ichthyofauna of

Nicaraguan Lakes

Papers in the Biological Sciences

1976

\title{
Serum Protein Variation in the Bull Shark, Carcharhinus Leucas Müller and Henle, 1841
}

C. Michael Cowan

Associated Environmental Services Corp.

Follow this and additional works at: https://digitalcommons.unl.edu/ichthynicar

Part of the Aquaculture and Fisheries Commons

Cowan, C. Michael, "Serum Protein Variation in the Bull Shark, Carcharhinus Leucas Müller and Henle, 1841" (1976). Investigations of the Ichthyofauna of Nicaraguan Lakes. 45.

https://digitalcommons.unl.edu/ichthynicar/45

This Article is brought to you for free and open access by the Papers in the Biological Sciences at DigitalCommons@University of Nebraska - Lincoln. It has been accepted for inclusion in Investigations of the Ichthyofauna of Nicaraguan Lakes by an authorized administrator of DigitalCommons@University of Nebraska Lincoln. 


\title{
SERUM PROTEIN VARIATION IN THE BULL SHARK, CARCHARHINUS LEUCAS MÜLLER AND HENLE, 1841*
}

\author{
G. MICHAEL COWAN
}

Nebraska Wesleyan University, Lincoln, Nebraska, U.S.A.

(Received 23 June, 1971)

\begin{abstract}
I. A detailed electrophoretic study was made of different developmental stages of the bull shark, Carcharhinus leucas Müller and Henle, I84I.

2. Both qualitative and quantitative variations were found to exist between newborn and adult bull sharks.

3. Variations in the globulin portion may be related to the development of immunoglobulins.
\end{abstract}

ElECTROPHORETIC studies of elasmobranch serum proteins have been intermittently reported in the literature since Moore (1945). Irisawa and Irisawa (1954) published a paper describing analbuminaemia in 2 elasmobranchs, Raja kenojei and Heterodontus japonicus. Other authors have made similar observations: Drilhon (r96o), Bueker ( $196 \mathrm{r}$ ), Hess and Smith (1967), Rasmussen and Rasmussen (1967). Engle, Woods, Paulsen, and Pert (1958) suggested that the elasmobranch cathode fraction was similar in its electrophoretic properties to $\gamma$-globulin (implied immunoglobulin), which led to a series of studies: Clem and Sigel (1965), Marchalonis and Edelman (1965, I966), Papermaster (1965), Clem and Small (1966), Clem and DeBoutaud (1967), Clem, DeBoutaud, and Sigel ( 1967$)$, Suran, Tarail, and Papermaster (1967), Fidler, Clem, and Small (1969). Cordier, Barnoud, and Brandon (1957) studied the relationship between the serum proteins of Scyllium canicula and starvation.

* This investigation was supported in part by U.S. Public Health Grant No. 09075 to Thomas B. Thorson and with National Science Foundation funds in support of the $\mathrm{R} / \mathrm{V}$ Rhincodon at the Mote Marine Laboratory. The work was conducted while the author held Graduate Educational Grant in Aquatic Sciences (U.S.D.I., Bureau of Commercial Fisheries) No. 14-1 7-007408(G). Studies for the Department of Zoology, University of Nebraska No. $44^{\circ}$.
None of the papers mentioned above deals with large numbers of one species or representatives of different developmental stages of one species. Consequently, serum collections of the bull shark, Carcharhinus leucas Müller and Henle, I84I, were begun in 1965 and continued throughout 1967 . This species was chosen for several reasons:-

I. It is commonly taken in shallow, tropical and sub-tropical waters.

2. It inhabits freshwater rivers and lakes in many parts of the world (Thorson, Cowan, and Watson, I966; Thorson, Watson, and Cowan, I966), which is unusual for most elasmobranchs and may be of evolutionary importance.

3. An established collecting site at Barra del Colorado, Costa Rica, yields many individuals representing nearly all stages of development.

4. Large marine specimens were readily available at the Mote Marine Laboratory in Sarasota, Florida. Thus, an elasmobranch was chosen from which many samples could be collected representing different developmental stages and variations in habitat.

\section{METHODS}

Bull sharks collected at Barra del Colorado, Costa Rica, were taken as a part of a larger study by Dr. Thomas B. Thorson of the University of Nebraska. Marine specimens were provided by 
the Mote Marine Laboratory, Sarasota, Florida. Blood samples were obtained by direct cardiac puncture or by cannulation of the caudal vein. Blood samples were refrigerated during clot formation and then centrifuged at 2500 r.p.m. The serum was then decanted and frozen until analysed, for a period of usually not more than 2 weeks.

Electrophoretic separations were achieved with a C.L. Davis Linear Disk Electrophoresis Chamber and an Isco Model 490 Regulated Power Supply, after a method described by Clarke (1 964 ). Total protein was determined by the biuret method (Weichselbaum, I946) and urea by the diacetyl monoxime method of Fearon (1939).

\section{RESULTS}

Both qualitative and quantitative variations were found to exist at different stages of

Table 1.- Total Protein of Bull Sharks in Lake Nicaragua (Fresh Water ioo + Miles from the SEA)

\begin{tabular}{|c|c|c|c|}
\hline $\begin{array}{l}\text { Specimen } \\
\text { No. }\end{array}$ & SEX & $\begin{array}{l}\text { SizE } \\
(\mathrm{cm} .)\end{array}$ & $\begin{array}{l}\text { Total Protein } \\
\text { (g. per i } 00 \mathrm{ml} \text {.) }\end{array}$ \\
\hline $65-3$ & M & $99^{\prime} \mathrm{I}$ & $3 \cdot I$ \\
\hline $65-4$ & $F$ & $133^{\circ} 0$ & $3 \cdot 2$ \\
\hline $65-5$ & F & 1243 & 3.3 \\
\hline $65-7$ & M & $129 \cdot I$ & $3 \cdot 2$ \\
\hline $65-8$ & $\mathrm{~F}$ & 145.0 & $3 \cdot I$ \\
\hline $65^{-1}$ & $F$ & I I $5^{\circ} \mathrm{O}$ & $2 \cdot 8$ \\
\hline $65^{-12}$ & M & $120 \cdot 2$ & $3 \cdot 3$ \\
\hline $65-13$ & $\mathbf{M}$ & 170.5 & $3 \cdot 4$ \\
\hline $65-16$ & M & I I $2 \cdot 0$ & $3 \cdot 1$ \\
\hline $65^{-17}$ & $\mathbf{M}$ & I 79.5 & $3 \cdot 1$ \\
\hline $65-18$ & $\mathbf{F}$ & I 88.5 & $2 \cdot 6$ \\
\hline $65-19$ & $\mathrm{~F}$ & I 37.5 & $2 \cdot 8$ \\
\hline $6_{5}-22$ & $\mathrm{~F}$ & I 25.8 & $3 \cdot 2$ \\
\hline
\end{tabular}

Mean $=3 \cdot r$. Range of variation $=2 \cdot 6-3 \cdot 4$. Standard deviation $=0 \cdot 3$. Confidence interval at $t=0.05$ is $2 \cdot 4-3.8$. Number of specimens $=13$.

development in the bull shark. The mean total protein value of bull sharks less than $100 \mathrm{~cm}$. in length was $1.92 \mathrm{~g}$. per cent (S.D. $=0.14$ ) while those greater than $100 \mathrm{~cm}$. had a mean value of $2.99 \mathrm{~g}$. per cent (S.D. $=$ $0 \cdot 4 \mathrm{I})$. The quantitative change in total serum protein apparently occurs when bull sharks attain lengths of $\pm 100 \mathrm{~cm}$. An attempt was made to correlate changes in total protein between bull sharks living in sea water having high concentrations of urea with those from fresh water and reduced concentrations (Tables I, II, III). Careful analysis of these results indicates that the total serum protein is apparently not a function of the urea concentration or habitat. (Data pertaining to urea concentration and

Table II.-Total Protein of Bull Sharks taken at Barra del Colorado, Costa Riga (very NEAR THE SEA)

\begin{tabular}{|c|c|c|c|}
\hline $\begin{array}{l}\text { SPECIMEN } \\
\text { No. }\end{array}$ & SEX & $\begin{array}{l}\text { SIZE } \\
(\mathrm{cm} .)\end{array}$ & $\begin{array}{l}\text { Total Protein } \\
\text { (g. per ioo ml.) }\end{array}$ \\
\hline $66-2$ & $\mathbf{M}$ & I 24.6 & $3 \cdot 3$ \\
\hline $66-3$ & $\mathrm{~F}$ & $121 \cdot 0$ & $\begin{array}{l}3.3 \\
3 \cdot 1\end{array}$ \\
\hline $66-4$ & M & I $76 \cdot 7$ & $2 \cdot I$ \\
\hline $66-5$ & $\mathrm{~F}$ & 177.5 & $3 \cdot 3$ \\
\hline $66-6$ & $\mathrm{M}$ & I $49 \cdot 6$ & $2 \cdot I$ \\
\hline $66-7$ & $\mathrm{M}$ & $\mathrm{I} 6 \mathrm{I} \cdot 2$ & $2 \cdot 2$ \\
\hline $66-8$ & M & $12 \mathrm{r} \cdot 6$ & $2 \cdot 4$ \\
\hline $66-9$ & $F p^{\star}$ & $222 \cdot 0$ & $2 \cdot I$ \\
\hline 66-10 & Fut & $66 \cdot 3$ & I 9 \\
\hline $66-17$ & $\mathbf{M}$ & I $35^{\circ} 0$ & $3 \cdot I$ \\
\hline $66-$ I 8 & $\mathbf{F}$ & I $32 \cdot 0$ & $2 \cdot 7$ \\
\hline $66-$ I9 & F & $208 \cdot 0$ & $2 \cdot 6$ \\
\hline $66-20$ & $\mathbf{M}$ & 128.0 & $3 \cdot 8$ \\
\hline $66-23$ & F & I I $8 \cdot 0$ & $2 \cdot 7$ \\
\hline $66-24$ & M & I $29 \cdot 6$ & $3 \cdot 2$ \\
\hline $66-25$ & M & $132 \cdot 0$ & 3.0 \\
\hline $67-9$ & F & $56 \cdot 0$ & $\mathrm{I} \cdot 8$ \\
\hline $67-10$ & $\mathrm{Fp}$ & $202 \cdot 0$ & $4^{\circ} \mathrm{O}$ \\
\hline $67-$ I I & $\mathrm{Fu}$ & $62 \cdot 0$ & $I \cdot 9$ \\
\hline $67-12$ & $\mathrm{Fu}$ & $62 \cdot 0$ & I $\cdot 9$ \\
\hline $67-13$ & $\mathrm{Fu}$ & 63.0 & 1.8 \\
\hline $67-14$ & M & $128 \cdot 0$ & $2 \cdot 5$ \\
\hline $67-15$ & M & ${ }^{1} 67 \cdot 0$ & $3 \cdot 7$ \\
\hline $67-16$ & $\mathbf{M}$ & $72 \cdot 2$ & I. 9 \\
\hline $67-17$ & $\mathbf{M}$ & $65 \cdot 5$ & $2 \cdot 4$ \\
\hline $67-18$ & $\mathrm{Fp}$ & $210 \cdot 2$ & $3 \cdot 3$ \\
\hline $67-19$ & $\mathrm{Fu}$ & $59 \cdot 3$ & $2 \cdot 0$ \\
\hline $67-20$ & Fu & $6 \mathrm{I} \cdot 0$ & $1 \cdot 7$ \\
\hline $67-21$ & $\mathrm{Fu}$ & $67 \cdot 0$ & $2 \cdot I$ \\
\hline $67-22$ & Muł & $52 \cdot 2$ & $2 \cdot 3$ \\
\hline $67-23$ & $\mathrm{Mu}$ & $45 \cdot 8$ & $2 \cdot 0$ \\
\hline $67-24$ & $\mathbf{M u}$ & $57 \cdot 0$ & I 6 \\
\hline
\end{tabular}

Mean $=2 \cdot 5$. Range of variation $=\mathrm{I} \cdot 6-4 \cdot 0$. Standard deviation $=0 \cdot 7$. Confidence interval at $t=0.05$ is $\mathrm{I} \cdot \mathrm{I}-3.9$. Number of specimens $=32$.

$\star \mathrm{Fp}=$ Pregnant female.

$+\mathrm{Fu}=$ Uterine female.

$\ddagger \mathrm{Mu}=$ Uterine male.

habitat are to be published in the near future.)

Qualitative variation was quite pronounced at differing stages of development. Fig. I shows the 'typical' bull shark pattern 
alongside a human control serum. Fig. 2 compares an adult pattern with that of a uterine pup, and Fig. 3 the variation which exists between 2 male shark pups from the same uterus. Electrophoretic serum protein patterns obtained from uterine shark pups gave no indication that the globulin protein

Table III.-Total Protein of Bull Sharks taken in the Gulf of Mexico (Marine)

\begin{tabular}{l|l|l|c}
\hline Specimen & Sex & $\begin{array}{c}\text { Size } \\
\text { (cm.) }\end{array}$ & $\begin{array}{c}\text { Total Protein } \\
\text { (g. per ioo ml. }\end{array}$ \\
\hline C67-1 & F & $242 \cdot 0$ & $3 \cdot 7$ \\
C67-2 & M & $220 \cdot 5$ & $2 \cdot 6$ \\
C67-3 & F & $239 \cdot 0$ & $2 \cdot 4$ \\
C67-4 & F & $224 \cdot 0$ & $3 \cdot 6$ \\
C67-5 & M & $209 \cdot 0$ & $3 \cdot 9$ \\
C67-7 & F & $260 \cdot 0$ & $3 \cdot 1$ \\
C67-10 & M & $202 \cdot 0$ & $3 \cdot 6$ \\
\hline
\end{tabular}

Mean $=3 \cdot 3$. Range of variation $=2 \cdot 4-3 \cdot 9$. Standard deviation $=0 \cdot 6$. Confidence interval $=\mathrm{r} \cdot 9$ 4.7. Number of specimens $=7$.

polymorphisms were sex-related, although there did appear to be a tendency for the most rapid non-globulin fraction to show

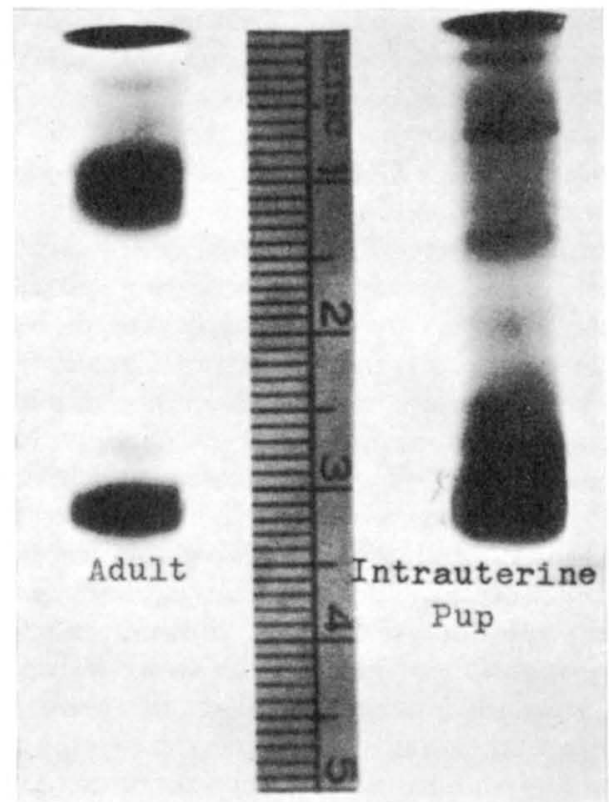

FiG. 2.-Comparison of an adult bull shark serum protein with that of a uterine pup.

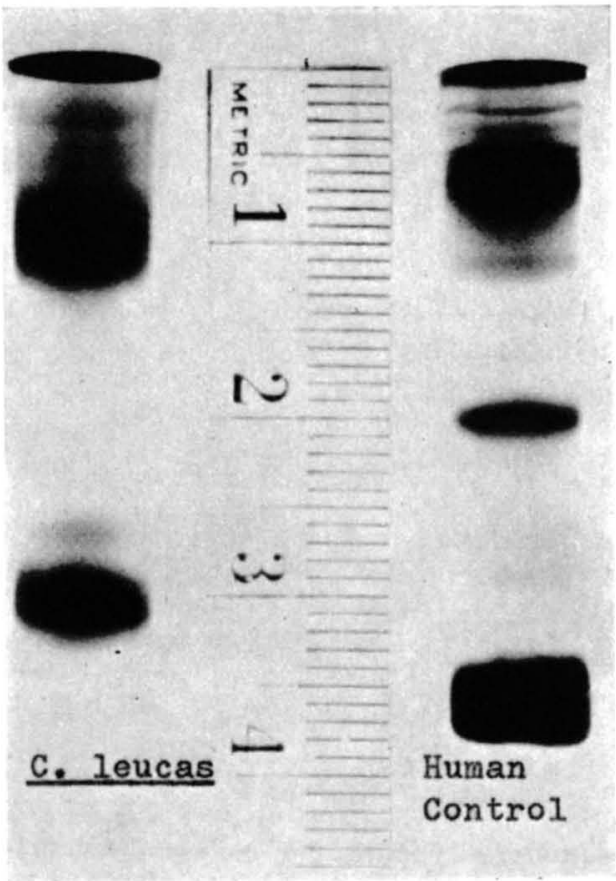

Fig. I.-Serum protein pattern of an adult bull shark compared to a human control serum.

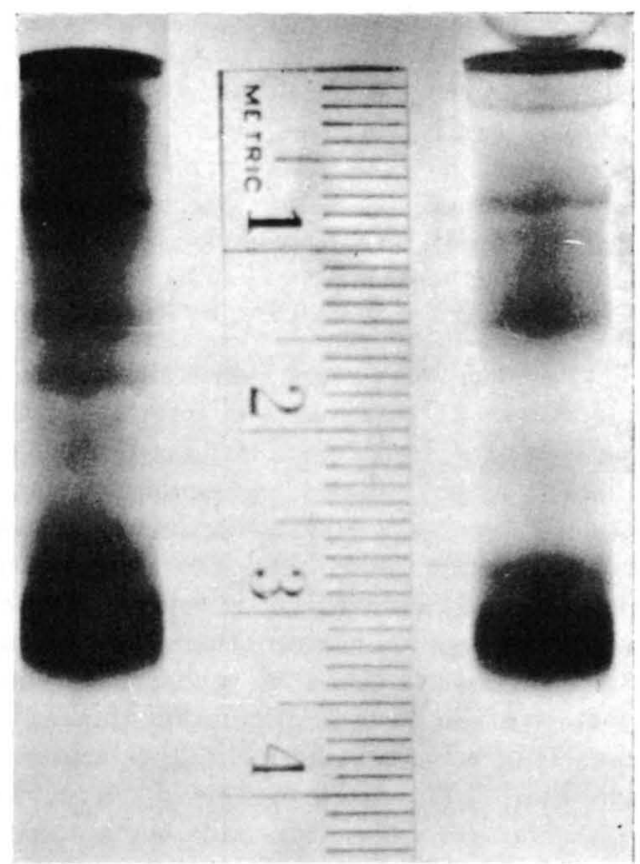

Fig. 3.-Ciomparison of dissimilar protein patterns obtained from 2 male shark pups occupying the same uterus. 


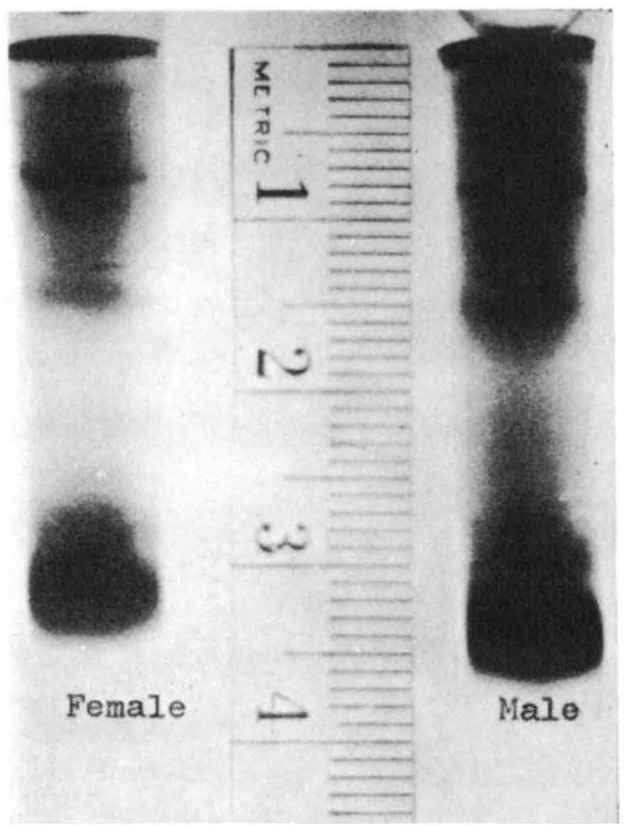

Fig. 4.-Comparison of male and female bull shark pups taken from the same uterus, showing similar globulin proteins and dissimilar mobility of the leading fraction.

differences related to sex (Fig. 4). The globulins appeared to be developmental and uterine, and juvenile globulin proteins developed into the adult type at approximately the same point at which total protein reached adult levels, $\pm 100 \mathrm{~cm}$.

\section{DISCUSSION}

The quantitative variation which occurs in bull sharks at differing life stages is quite interesting in view of the fact that Fidler and others (1969) found no such variation between newborn and adult nurse sharks. In most cases shark pup sera were easily distinguished from adult sera by total protein values alone. Fidler and others (1969) state: 'Approximately one-half the adult shark serum protein is immunoglobulin and newborn sharks have relatively little immunoglobulin.' This statement would agree well with these findings, especially when taking into consideration lower quantities of total protein in neonatal bull sharks. The electrophoretic pattern in Fig. 2 suggests that the proteins involved are those having the characteristics of globulins. It would seem, then, that these juvenile globulin proteins could represent stages in the development of the immunoglobulins, and immunological activity would ensue with the possible polymerization of the neonatal protein moieties. The remainder (approximately $5^{\circ}$ per cent) of the juvenile protein, which is very similar to that of the adult, is a very large fraction with relatively high electrophoretic mobility. This fraction has not been thought of as an albumin since publication by Irisawa and Irisawa in 1954. However, though its electrophoretic mobility is not equivalent to human albumin, some of its other properties are quite similar. In one instance it was observed that this fraction bound Bromphenol Blue dye, a characteristic of human serum albumin. The sample involved in this case was one taken from a bull shark in 8 o per cent sea water. One could interpret this dye-binding capacity as a function of the osmotic environment. (Dye binding in albumin has been explained (Haurowitz, I96I) as an unfolding and refolding of the protein molecule, allowing dye particles to be caught in the tertiary structure of the protein.) In this case the osmotic conditions may have been such that dye binding was possible. The dye-binding capacity was observed only in I available specimen taken from 80 per cent sea water. The precipitation behaviour of this fraction in sodium sulphate is also similar to that of human albumin. It is, in fact, possible to estimate the albumin/ globulin ratio by precipitating the globulins and measuring the quantity of protein left. Of 4 samples measured, the albumin/ globulin ratio ranged from 0.59 to 0.72 with a mean of 0.67 . Fig. 5 indicates the fractionation achieved with 28 per cent sodium sulphate. Although this is a crude fractionation process, it does indicate a similarity in the solubility of human albumin and the questionable protein in bull shark serum.

It would appear, based on the above evidence, that bull shark pups have globulin proteins which most likely represent stages in the development of immunoglobulin and an 'albumin ' fraction similar to that found 
in adult individuals. This work also suggests that the habitat does not affect total protein concentration, indicating, as one would suspect because of the high urea concentration, that the serum protein does not play an important role in maintaining osmotic pressures in bull sharks. A last observation is that

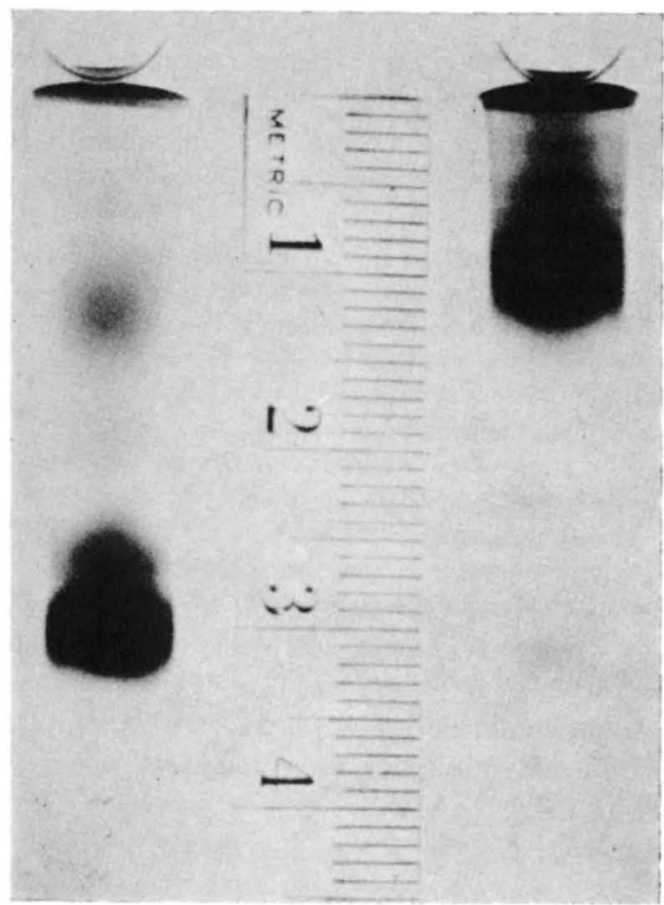

Fig. 5.-Comparison of the protein patterns obtained by fractionation of adult bull shark serum with 28 per cent sodium sulphate. The globulin portion appears on the left.

serum proteins, because they are so highly variable, are not valuable as species indicators in elasmobranchs. This last point, which has been suggested by others, might also be applied to other fishes as well, in that it is apparently necessary to have samples at different stages of development before making species interpretations based on serum protein differences.

\section{REFERENCES}

Bueker, E. (196I), 'Paper electrophoretic patterns of human serum proteins compared with those of lower forms', Proc. Soc. exp. Biol. Med., 106, 373-377.
Cllarke, J. T. (1964), 'Simplified disc (polyacrylamide gel) electrophoresis', $A n n$. N.r. Acad. Sci., 121, $428-436$.

Clem, L. W., and DeBoutaud, F. (1967), ' Studies in elasmobranch immunoglobulins', in Sharks, Skates and Rays (ed. Gilbert, P. W., Mathew-

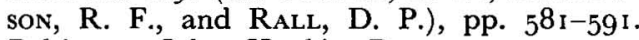
Baltimore: Johns Hopkins Press.

Clem, L. W., DeBoutaud, F., and Sigel, M. M. ( 1967$)$, 'Immunoglobulins of the nurse shark', F. Immun., 99, I 226-1 235 .

Glem, L. W., and Sigel, P. A. (1965), 'Antibody responses of vertebrates to bovine serum albumins', Fedn Proc. Fedn Am. Socs exp. Biol., 24, 2079.

Clem, L. W., and Small, P. A. (1966), 'Immunoglobulins of the lemon shark', F. exp. Med., 125, 893-920.

Cordier, D., Barnoud, R., and Brandon, A. M. (I957), 'Étude sur la proteinemie de la roussette (Scyllium canicula L.). Influence du jeune', C. r. Séanc. Soc. Biol., r51, 1912-1915.

Drilhon, A. (1960), ' L'apport de l'electrophorèse en gel d'amidon a l'étude des proteines sériques des poissons', Bull. Inst. océanogr. Monaco, No. i 68.

Engle, R. L., Woods, K. R., Paulsen, E. C., and Pert, J. H. (1958), 'Plasma cells and serum proteins in marine fish', Proc. Soc. exp. Biol. Med., 98, 905-909.

Fearon, W. (1939), "The carbamido diacetyl reaction: a test for citrulline', Biochem. $7 ., 33$, 902-907.

Fidler, J. E., Clem, L. W., and Small, P. A. (1969), ' Immunoglobulin synthesis in neonatal nurse sharks (Ginglymostoma cirratum) ', Comp. Biochem. Physiol., 31, 365-371.

Haurowitz, F. (1961), " The role of blood plasma in bodily maintenance and repair ', in Function of the Blood (ed. Macfarlane, R. G., and Roвb-Smith, A. H. T.), pp. 527-588. New York: Academic Press.

Hess, P. W., and Smith, R. A. (1967), 'Electrophoresis of elasmobranch serum protein with cellulose acetate', Trans. Am. Fish Soc., 96, I 3 I-I 33 .

IrisaWA, H., and Irisawa, A. F. (I954), 'Blood serum protein of the marine elasmobranch', Science, $\mathcal{N} . Y_{\text {., }}$ r20, $849-851$.

Marchalonis, J., and Edelman, G. M. (1965), 'Multichain structure of immunoglobulins in the smooth dogfish (Mustelus canis)', J. exp. Med., 122, 60 I-6I8.

Marchalonis, J. and Edelman, G. M. (1966), 'Peptide chains of immunoglobulins from the smooth dogfish (Mustelus canis)', Science, N.Y., 154, $1567-1568$.

MOORE, D. H. (1945), 'Species differences in serum protein patterns ', $\mathcal{7}$. biol. Chem., r61, 2 I-32.

Papermaster, B. W. (1965), 'An immunoglobulin fraction from the leopard shark', Fedn Proc. Fedn Am. Socs exp. Biol., 24, 2079 (Abstract). 
Rasmussen, L. E., and Rasmussen, R. A. (1967), ' Comparative protein and enzyme profiles of the cerebrospinal fluid, extradural fluid, nervous tissue and sera of elasmobranchs', in Sharks, Skates and Rays (ed. Gilbert, P. W., Mathewson, R. F., and RaLl, D. P.), pp. 36I-379. Baltimore: Johns Hopkins Press.

Suran, A. A., Tarail, M. H., and Papermaster, B. W. (1967), 'Isolation and characterization of $\mathrm{r} \mathrm{S}$ and ${ }_{7} \mathrm{~S}$ immunoglobulins with precipitating activity', 7. Immun., 99, 679-686.

Thorson, T. B., Cowan, C. M., and Watson, D. E. (1966), "Sharks and sawfish in the Lake Izabal-Rio Dulce system, Guatemala ', Copeia, 3, 620-622.
Thorson, T. B., Watson, D. E., and Cowan, C. M. (I966), "The status of the freshwater shark in Lake Nicaragua', Copeia, 3, 385-402. Weichselbaum, T. E. (1946), 'An accurate and rapid method for the determination of proteins in small amounts of blood serum and plasma', Am. 7. clin. Path., 7, 40-49.

Key Word Index: Serum protein, neonatal sharks, Carcharhinus leucas, disk electrophoresis, analbuminaemia, qualitative variation, quantitative variation. 